\title{
Pengaruh Kualitas Aset dan Kualitas Modal Terhadap Profitabilitas dengan Likuiditas Sebagai Variabel Intervening Pada Sub Sektor Perbankan Di Bursa Efek Indonesia Periode 2015 - 2019
}

\author{
Pantun Bukit*, Rika Syahrianti \\ Magister Manajemen Universitas Batanghari \\ *Correspondence email: pantun.bukit@unbari.ac.id
}

\begin{abstract}
Penelitian ini akan melihat kinerja perusahaan perbankan, dengan melihat hubungan antara faktor kualitas asset, kualitas modal terhadap profitabilitas dengan likuiditas sebagai intervening pada sub sektor perbankan di Bursa Efek Indonesia periode 2015-2019. Penelitian ini menggunakan variabel bebas pertama yakni variabel kualitas aset dengan indikator yakni NPL Gross, NPL Net, dan RAPBTTAP. Variabel bebas ke dua yakni variabel kualitas modal dengan indikator yakni TIER 1, TIER 2, KPMM dan FAtE. Variabel terikat yakni profitabilitas dengan indikator yakni BOPO, ROA, ROE dan NIM. Variabel intervening yakni likuiditas dengan indikator yakni LDR, LtER dan LtTAR. Sampel penelitian yang digunakan adalah kelompok saham sub sektor perbankan selama 5 tahun periode pengamatan, dimulai dari tahun 2015 - 2019, yang memiliki laporan indikator penelitian yang lengkap dari laporan keuangan, tidak melakukan stock split dan memiliki indikator rasio profitabilitas negatif yakni sebanyak 11 emiten. Bentuk penelitian ini adalah penelitian eksplanatoris (explanatory research) dan analisis data dalam penelitian ini menggunakan Partial Least Square dengan menggunakan software Smart PLS 3.0. Hasil penelitian menunjukkan, variabel kualitas modal berpengaruh signifikan terhadap variabel likuiditas, variabel kualitas modal berpengaruh signifikan terhadap variabel likuiditas, Variabel kualitas aset berpengaruh signifikan terhadap variabel profitabilitas, kualitas modal tidak berpengaruh signifikan terhadap variabel profitabilitas, variabel likuiditas berpengaruh signifikan terhadap variabel profitabilitas, Variabel kualitas aset dan kualitas modal tidak berpengaruh signifikan terhadap variabel profitabilitas dengan variabel likuiditas sebagai variabel intervening.
\end{abstract}

Kata Kunci : Kualitas Aset, Kualitas Modal, Profitabilitas, Likuiditas, Variabel Intervening.

\begin{abstract}
This study will look at the performance of banking companies, looking at the relationship between asset quality factors, capital quality to profitability and liquidity as intervening in the banking sub-sector on the Indonesia Stock Exchange for the period 2015-2019. This study used the first free variable which is an asset quality variable with indicators namely NPL Gross, NPL Net, and RAPBTTAP. The second free variable is a capital quality variable with indicators namely TIER 1, TIER 2, KPMM and FAtE. Variables are tied to profitability with indicators namely BOPO, ROA, ROE and NIM. Intervening variable is liquidity with indicators namely LDR, LtER and LtTAR. The research sample used is a group of sub-banking sector stocks during the 5year observation period, starting from 2015 - 2019, which has a complete research indicator report of financial statements, does not conduct a stock split and has indicators of negative profitability ratios of 11 issuers. This form of research is explanatory research and data analysis in this study using Partial Least Square using Smart PLS 3.0 software. The results showed, capital quality variables have a significant effect on liquidity variables, capital quality variables have a significant effect on liquidity variables, Asset quality variables have a significant effect on profitability variables, capital quality has no significant effect on profitability variables, liquidity variables have a significant effect on profitability variables, Asset quality variables and capital quality have no significant effect on variable profitability with liquidity variables as intervening variables.
\end{abstract}

Keywords : Asset Quality, Capital Quality, Profitability, Liquidity, Intervening Variables.

\section{Pendahuluan}

Undang-Undang No. 10 Tahun 1998, mengemukakan bahwa pengertian perbankan merupakan segala sesuatu yang menyangkut tentang bank, mencakup kelembagaan, kegiatan usaha, serta cara dan proses dalam melaksanakan kegiatan usahanya. Fungsi utama bank adalah sebagai penghimpun dan penyalur dana dari masyarakat, memiliki peranan yang strategis untuk menunjang pelaksanaan pembangunan nasional dalam rangka peningkatan pemerataan pembangunan dan hasil-hasilnya, ke arah peningkatan taraf hidup rakyat banyak. Kinerja badan usaha bank secara keseluruhan dapa dilihat pada laporan keuangannya yang terdiri dari neraca, laporan laba rugi, laporan perubahan modal, laporan arus kas dan catatan atas laporan keuangan. Bagi perusahaan, jasa bank yang terpenting adalah bagaimana memilih dan mengelola sumber dana yang tersedia, terutama yang bersumber dana dari masyarakat yang terkumpul dalam bentuk simpanan giro, tabungan dan deposito. Strategi dan aktivitas manajemen operasional sebuah bank terlihat dalam neraca dan perubahan neraca maupun aktifitas operasionalnya, laporan laba ruginya yang mencerminkan bagaimana perusahaan perbankan tersebut dalam menjalankan dan melaksanakan kegiatannya baik dari sisi asset yang dimiliki, permodalan, laba yang diperoleh, hutang yang dimiliki dan lainnya.

Penelitian ini akan melihat kinerja perusahaan perbankan, dengan melihat hubungan antara faktor kualitas asset, kualitas modal terhadap profitabilitas dengan likuiditas sebagai perantaranya. Penilaian kualitas aset merupakan 
penilaian terhadap kondisi aset bank dan kecukupan manajemen risiko kredit. Kelangsungan usaha bank tergantung pada kesiapan untuk menghadapi risiko kerugian dari penanaman dana. Bagi bank yang mempunyai tingkat kolektibilitas yang tinggi dan mempunyai earning asset yang memadai maka kebutuhan modalnya akan dapat diperoleh dari laba usaha bank yang bersangkutan, dan sebaliknya apabila bank tersebut rugi terus menerus maka ada kemungkinan pula modalnya akan terkikis sedikit demi sedikit. Penelitian ini akan menggunakan variabel bebas pertama yakni variabel kualitas aset dengan menggunakan indikator antara lain yakni Non Performing Loan (NPL) Gross, Non Performing Loan (NPL) Net, dan Rasio Aktiva Produktif Bermasalah Terhadap Total Aset Produktif (RAPBTTAP) yang dipublikasikan oleh kelompok perusahaan emiten sub sektor perbankan pada Bursa Efek Indonesia pada tahun 2015 - 2019.

Selain variabel kualitas asset, penelitian ini juga menggunakan variabel kualitas modal, peningkatan kualitas dan kuantitas modal bank akan mampu menyerap potensi kerugian yang dialaminya sebagai contoh akibat situasi keuangan dan ekonomi yang ada pada makro ekonomi suatu negara, maupun karena pertumbuhan kredit yang berlebihan, persyaratan komponen dan instrumen modal serta perhitungan kecukupan modal bank perlu disesuaikan dengan standar yang berlaku yang dikeluarkan oleh pemerintah baik Bank Indonesia maupun Otoritas Jasa Keuangan. Variabel kualitas modal dengan menggunakan indikator antara lain yakni modal inti (TIER 1), modal pelengkap (TIER 2), Kewajiban Penyediaan Modal Minimum (KPMM) dan Fixed Asset to Equity (FAE) yang dipublikasikan oleh kelompok perusahaan emiten sub sektor perbankan. Semakin besar modal yang dimiliki oleh suatu bank akan meningkatkan rasio kecukupan modalya, sebaliknya bila modal perusahaan terus menerus terkikis oleh kerugian yang dialami bank, maka kualitas kecukupan modal bank akan turun, ini disebabkan karena kerugian yang dialami bank akan menyerap modal yang dimiliki bank.

Bank yang selalu dapat menjaga kinerjanya dengan baik yaitu bank yang mampu menjaga tingkat profitabilitas yang tinggi. Tingkat profitabilitas bank menjadi suatu hal penting karena bank yang sehat adalah bank yang diukur secara profitabilitas yang terus meningkat. Jumlah keuntungan (laba) yang diperoleh secara teratur serta kecenderungan keuntungan yang meningkat merupakan suatu faktor penting dalam menilai profitabilitas suatu bank. Profitabilitas merupakan penilaian terhadap kondisi kemampuan bank dalam menghasilkan laba untuk mendukung operasional dan permodalan. Profitabilitas tidak hanya menunjukkan jumlah kuantitas dan trend laba saja, tetapi juga faktor-faktor yang mempengaruhi ketersediaan dan kualitas laba (Kuncoro, 2002). Variabel profitabilitas dengan menggunakan indikator antara lain yakni Biaya Operasional Pendapatan Operasional (BOPO), Return on Asset (ROA), Return on Equity (ROE) dan Net Interest Margin (NIM) yang dipublikasikan oleh kelompok perusahaan emiten sub sector perbankan.

Penelitian ini juga menggunakan indikator likuiditas sebagai variabel intervening, dimana likuiditas merupakan kepemilikan sumber dana yang memadai untuk seluruh kebutuhan dan kewajiban yang akan jatuh tempo terutama jangka pendek. Pengelolaan likuiditas merupakan masalah yang cukup kompleks dalam kegiatan operasi bank yang akan berdampak pada profitabilitas bank dan keberlangsungan bisnis bank. Pengelolaan likuiditas disebabkan dana yang dikelola bank sebagian besar adalah dana masyarakat yang sifatnya jangka pendek dan dapat ditarik sewaktu-waktu, oleh karena itu bank harus memperhatikan seakurat mungkin kebutuhan likuiditas untuk suatu jangka waktu tertentu (Siamat, 2001). Variabel likuiditas dengan menggunakan indikator antara lain yakni Loan to Deposite Ratio (LDR), Liability to Equity Ratio (LtER), dan Liability to Total Asset Ratio (LtTAR) yang dipublikasikan oleh kelompok perusahaan emiten sub sektor perbankan. Tujuan penelitiam ini adalah untuk menganalisis pengaruh kualitas aset dan kualitas modal terhadap profitabiltas dengan likuiditas sebagai variabel intervening pada sub sektor perbankan di Bursa Efek Indonesia periode 2015 - 2019.

\section{Kajian Literatur}

Perusahaan bank sebagai lembaga intermediasi keuangan yang melakukan kegiatan operasionalnya dengan menghimpun dana dari masyarakat dan menyalurkan kembali dana tersebut kepada masyarakat serta memberikan jasa bank. Pendanaan bank bersumber dari simpanan dana masyarakat (dana pihak ketiga), dana dari lembaga lainnya (dana pihak kedua) dan dana modal sendiri (dana pihak pertama). Bagi perusahaan, jasa bank yang terpenting adalah bagaimana memilih dan mengelola sumber dana yang tersedia, terutama yang bersumber dana dari masyarakat yang terkumpul dalam bentuk simpanan giro, tabungan dan deposito. Strategi dan aktivitas manajemen operasional sebuah bank terlihat dalam neraca dan perubahan neraca maupun aktifitas operasionalnya, laporan laba ruginya yang mencerminkan bagaimana perusahaan perbankan tersebut dalam menjalankan dan melaksanakan kegiatannya baik dari sisi asset yang dimiliki, permodalan, laba yang diperoleh, hutang yang dimiliki dan lainnya.

Penilaian kualitas aset mencerminkan kemampuan manajemen bank dalam mengelola aktiva produktifnya. FASB dalam Concept No. 6 - Elements of Financial Statements of Business Enterprises menyatakan bahwa aktiva adalah manfaat ekonomis di masa yang akan datang yang diharapkan akan diterima oleh suatu badan usaha sebagai hasil dari transaksi-transaksi dimasa lalu. POJK No 40/POJK.03/2019, Tentang Penilaian Kualitas Asset Bank Umum 
di bentuk dan diberlakukan agar memperkuat peraturan yang telah ada supaya bank mempunyai tingkat kolektibilitas yang tinggi dan mempunyai earning asset yang memadai maka kebutuhan modalnya akan dapat diperoleh dari laba usaha bank yang bersangkutan, dan sebaliknya apabila bank tersebut rugi terus menerus maka ada kemungkinan pula modalnya akan terkikis sedikit demi sedikit, sehingga akan berpengaruh pada likuiditas perusahaan dan secara langsung jelas akan mempengaruhi profitabilitas perusahaan. Kualitas Aset yang baik tentu sangat penting bagi keberlangsungan kegiatan operasional bank tersebut yang juga akan berdampak pada kualitas modal yang dimiliki perusahaan..

Penjelasan pada peraturan Bank Indonesia No. 15/12/PBI/ 2013 tentang Kewajiban Penyediaan Modal Minimum Bank Umum, sebagai akibat dari pengalaman krisis keuangan dan ekonomi yang terjadi di berbagai negara pada beberapa tahun belakangan menunjukkan bahwa kejatuhan Bank antara lain disebabkan oleh tidak memadainya kualitas dan kuantitas permodalan Bank untuk mengantisipasi risiko yang dihadapi. Penjelasan dalam POJK No 11/POJK.03/2016, Tentang Kewajiban Penyediaan Modal Minimum (KPMM) Bank Umum diperkuat dalam rangka meningkatkan kualitas dan kuantitas modal bank sehingga bank lebih mampu menyerap potensi kerugian baik akibat krisis keuangan dan ekonomi maupun karena pertumbuhan kredit yang berlebihan, persyaratan komponen dan instrumen modal serta perhitungan kecukupan modal bank, sehingga tentu saja akan terkait terhadap likuiditas perusahaan perbankan.

Bank yang selalu dapat menjaga kinerjanya dengan baik yaitu bank yang mampu menjaga tingkat profitabilitas yang tinggi. Tingkat profitabilitas bank menjadi suatu hal yang penting karena bank yang sehat adalah bank yang diukur secara profitabilitas yang terus meningkat. Profitabilitas mengukur kemampuan bank dalam meningkatkan tingkat laba dan efisiensi usaha. Jumlah keuntungan (laba) yang diperoleh secara teratur serta kecenderungan atau tren keuntungan yang meningkat merupakan suatu faktor yang penting dalam menilai profitabilitas suatu bank sebagai dampak dari likuiditas yang ada pada bank tersebut. Likuiditas merupakan kepemilikan sumber dana yang memadai untuk seluruh kebutuhan dan kewajiban yang akan jatuh tempo terutama jangka pendek. Likuiditas merupakan kemampuan bank memenuhi semua kewajiban hutang-hutangnya dan dapat membayar kembali semua deposannya serta dapat memenuhi permintaan kredit yang diajukan tanpa terjadi penangguhan. Pengelolaan likuiditas merupakan masalah yang cukup kompleks dalam kegiatan operasi bank yang akan berdampak pada profitabilitas bank dan keberlangsungan bisnis bank, hal tersebut menggambarkan jika likuiditas naik maka laba bank juga akan naik.

\section{Hipotesis}

Hipotesis penelitian ini adalah :Kualitas aset dan kualitas modal berpengaruh signifikan terhadap profitabiltas dengan likuiditas sebagai variabel intervening pada sub sektor perbankan di Bursa Efek Indonesia periode 2015 2019.

\section{Metode}

Analisis data dalam penelitian ini menggunakan Partial Least Square dengan menggunakan software Smart PLS 3.0. Penelitian ini menggunakan analisis kausalitas SEM (Structural Equation Modeling) berbasis component atau variance yang terkenal dengan Partial Least Square (PLS), dengan menggunakan software Smart PLS 3.0. Partial Least Square merupakan suatu teknik statistik yang mampu menganalisis pola hubungan antara konstruk laten dan indikatornya, konstruk laten yang satu dengan lainnya, serta kesalahan pengukuran secara langsung. Partial Least Square memungkinkan dilakukannya analisis di antara beberapa variabel dependen dan independen secara langsung (Hair et al, 2009).

Pada variabel laten (konstruk) dalam penelitian ini terdapat indikator yang bersifat reflektif, yaitu arah panah variabel laten (konstruk) menuju ke indikator, yang berarti mengasumsikan kontruk laten mempengaruhi variasi pengukuran dan asumsi hubungan kausalitas dari konstruk laten ke indikator. Adapun ciri model indikator reflektif antaralain; Arah hubungan kausalitas dari variabel laten ke indikator, antar indikator diharapkan saling berkorelasi (memiliki internal consistency), menghilangkan satu indikator, tidak menghilangkan makna dan arti variabel yang diukur, kesalahan pengukuran (error) pada tingkat indikator. Model reflektif sering dikenal sebagai principal factor model dimana covariance pengukuran indikator dipengaruhi oleh konstruk laten atau mencerminkan variasi dari konstruk laten. Model ini menghipotesiskan bahwa perubahan pada konstruk laten akan mempengaruhi perubahan pada indikator. Menurut Ghozali (2008), PLS dimaksudkan untuk causal-perdictive analysis dalam situasi kompleksitas yang tinggi dan dukungan teori yang rendah.

Adapun penelitian ini akan mengikuti langkah-langkah pengujian model empiris penelitian berbasis PLS dengan software SmartPLS (Solimun dan Rinaldo, 2009) sebagai berikut:

1. Merancang Model Struktural (inner model), Perancangan model dalam Smart PLS, dapat dilakukan antara lain dapat berupa: teori, hasil empiris, anologi, hubungan antar variabel pada bidang ilmu lain, normatif, misal 
peraturan pemerintah, undang-undang, dan sebagainya dan rasional. Penelitian ini untuk menguji pengaruh kualitas aset dan kualitas modal terhadap profitabilitas yang dimoderasi oleh likuiditas. Perancangan model berdasarkan kerangka pemikiran berupa hubungan antar variabel pada Smart PLS dalam penelitian ini didasarkan pada: teori, hasil penelitian empiris, dan rasional.

2. Merancang model pengukuran (outer model), merancang model pengukuran yang dimaksud dalam PLS adalah menentukan sifat indikator dari masing-masing variabel laten, bersifat reflektif atau formatif. Dasar yang digunakan sebagai rujukan untuk menentukan sifat indikator apakah reflektif atau formatif adalah teori, penelitian empirirs atau rasional. Tahap awal penerapan PLS mengesankan bahwa rujukan berupa teori atau penelitian empiris sebelumnya masih jarang atau bahkan belum ada. Merujuk pada definisi konsep dan operasional variabel, indikatornya bersifat reflektif atau formatif.

3. Mengkonstruksi diagram jalur, Setelah melakukan perancangan inner model dan outer model selanjutnya dinyatakan dalam bentuk diagram jalur. Bentuk diagram jalur perancangan inner model dan outer model dalam penelitian ini diilustrasikan dalam gambar 1.

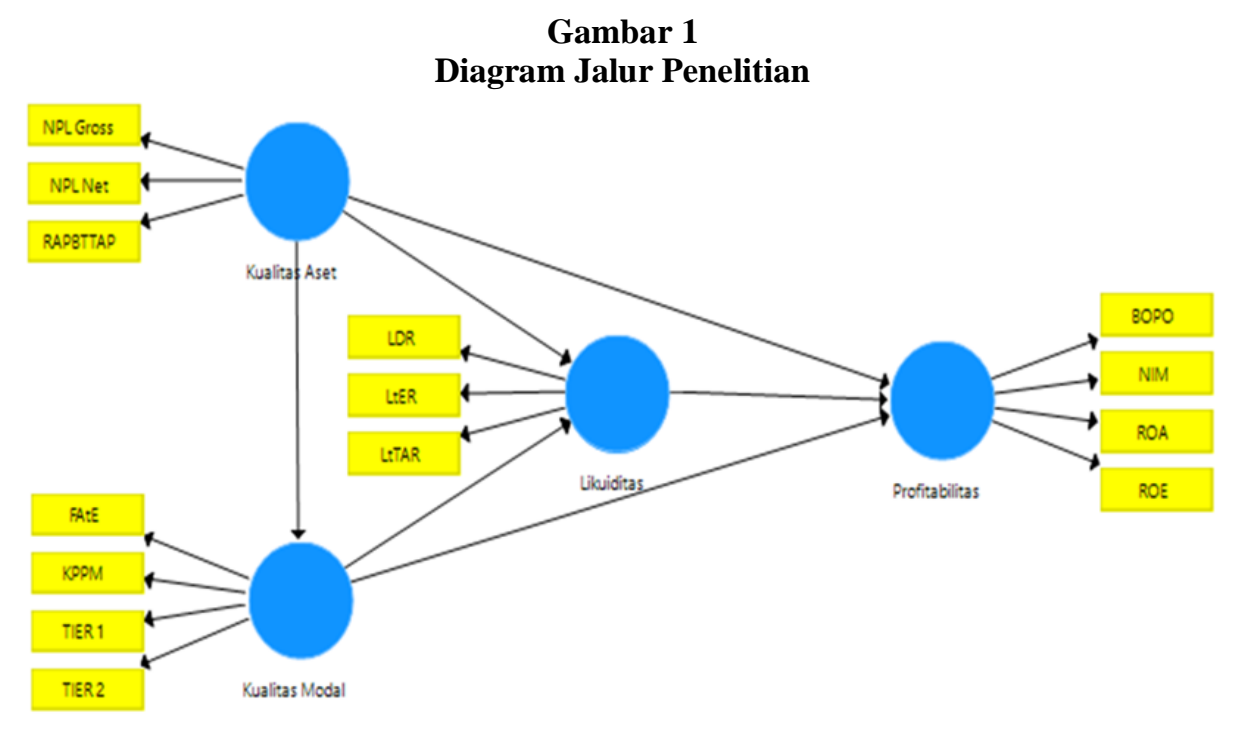

4. Koefisien Jalur (path coefficients), metode pendugaan parameter (estimasi) di dalam PLS adalah metode kuadrat terkecil (least square methods). Proses perhitungan dilakukan dengan cara iterasi, dimana iterasi akan berhenti jika telah tercapai kondisi konvergen.

5. Pengujian Hipotesis Penerapan metode resampling, yang memungkinkan berlakunya data terdistribusi bebas (distribution free), tidak memerlukan asumsi distribusi normal, serta tidak memerlukan sampel yang besar (direkomendasikan sampel minimum 10). Bilamana hasil pengujian hipotesis pada outer model signifikan, indikator dapat digunakan sebagai instrumen pengukur variabel laten.

6. Evaluasi Goodness of Fit, Semua variabel laten dalam penelitian ini menggunakan pengukuran model indikator reflektif. Model struktural atau inner model dievaluasi dengan melihat persentase varian yang dijelaskan yaitu dengan melihat $\mathrm{R}^{2}$. Stabilitas dari estimasi ini dievaluasi dengan menggunakan nilai $\mathrm{P}$ values yang didapat lewat prosedur bootstrapping. Goodness of Fit Model diukur menggunakan $R$-square variabel laten dependen.

\section{Hasil}

Tabel 1

Nilai Construct Reliability and Validity PLS algorithm kelima

\begin{tabular}{|l|r|r|r|r|}
\hline & \multicolumn{1}{|c|}{ Cronbach's Alpha } & \multicolumn{1}{c|}{ rho_A } & Composite Reliability & Average variance Extracted \\
\hline Kualitas Aset & 0.972 & 0.975 & 0.982 & 0.947 \\
\hline Kualitas Modal & 0.875 & 0.882 & 0.941 & 0.888 \\
\hline Likuiditas & 0.911 & 0.921 & 0.957 & 0.918 \\
\hline Profitabilitas & 0.867 & 0.887 & 0.920 & 0.794 \\
\hline
\end{tabular}

Sumber : olahan data

Berdasarkan tabel 1. terlihat nilai Cronbach's Alpha pada semua variabel tersebut mempunyai nilai diatas 0,7 hal tersebut menggambarkan bahwa uji reliabilitas telah memenuhi syarat atau tidak memiliki masalah pada kelayakan 
Pantun Bukit dan Rika Syahrianti, Pengaruh Kualitas Aset dan Kualitas Modal Terhadap Profitabilitas dengan Likuiditas Sebagai Variabel Intervening Pada Sub Sektor Perbankan di Bursa Efek Indonesia Periode 2015 - 2019

datanya. Hasil calculate (perhitungan) PLS algorithm kelima dengan menggunakan software Smart PLS 3.0 terlihat pada gambar berikut:

Gambar 2

Model Algorithm kelima.

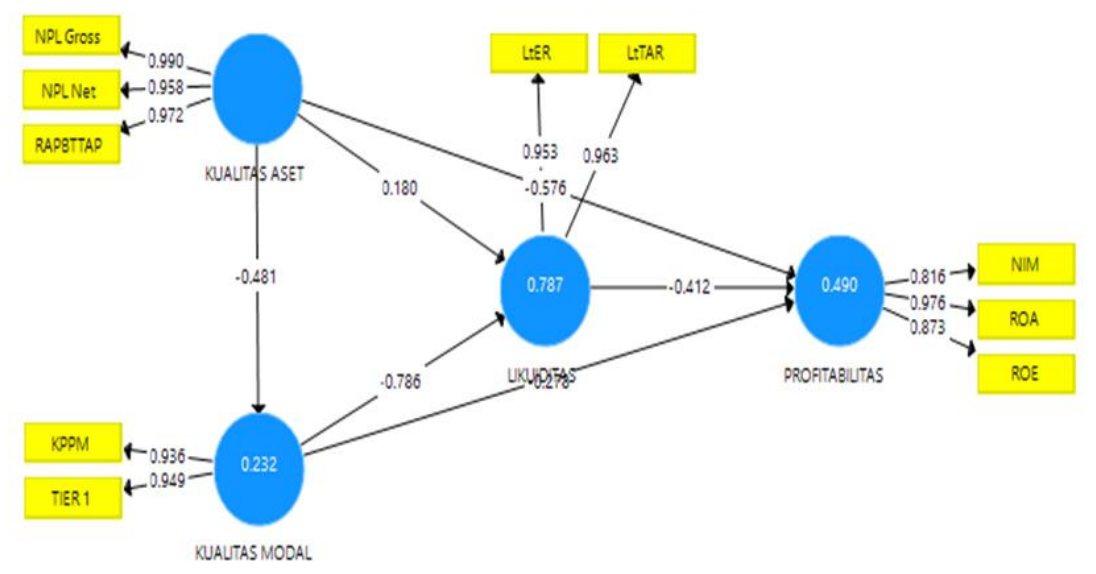

Pada gambar 2 dan Tabel 2 terlihat bahwa pada indikator variabel penelitian yakni kualitas asset, kualitas modal, likuiditas dan profitabilitas telah memiliki nilai loading factor diatas 0,7 (Cronbach's Alpha) dan 0,5 (Average Variance Extracted), hal tersebut menggambarkan bahwa uji reliabilitas dan validitas telah memenuhi syarat atau telah memiliki kelayakan data, dengan demikian indikator-indikator tersebut merupakan indikator yang reliabel dan valid sebagai indikator yang merefeksikan variabel penelitian ini. Langkah selanjutnya kita akan melihat besarnya Collinearity Statistic (VIF), yang akan memberikan gambaran tentang apakah data tersebut terjadi multikolinearitas atau tidak. Tabel 3 nilai inner loading VIF (inner VIF values) menunjukkan tidak terjadi multikolinearitas dimana pada variabel tersebut mempunyai nilai kurang dari 5, warna hijau menunjukkan bahwa variabel tersebut adalah layak yakni variabel kualitas modal dan variabel likuiditas serta warna hitam menunjukkan bahwa indikator tersebut masih dapat diterima yakni variabel profitabilitas. Hasil bootstraping juga menghasilkan tabel result for outer loadings. Tabel ini menggambarkan kemampuan merefleksikan dan signifikansi indikator terhadap variabelnya.

Tabel 2

Nilai outer loading PLS algorithm kelima

\begin{tabular}{|c|c|c|c|c|}
\hline & Kualitas Aset & Kualitas Modal & Likuiditas & Profitabilitas \\
\hline KPMM & & 0.936 & & \\
\hline LtER & & & 0.953 & \\
\hline LtTAR & & & 0.963 & \\
\hline NIM & & & & 0.816 \\
\hline NPL Gross & 0.990 & & & \\
\hline NPL Net & 0.958 & & & \\
\hline RAPBTTAP & 0.972 & & & \\
\hline $\mathrm{ROA}$ & & & & 0.976 \\
\hline ROE & & & & 0.873 \\
\hline TIER 1 & & 0.949 & & \\
\hline
\end{tabular}

Sumber : olahan data

Tabel 3

Nilai VIF (Variance Inflation Factors)

\begin{tabular}{|l|c|c|r|r|}
\hline & Kualitas Aset & Kualitas Modal & \multicolumn{1}{c|}{ Likuiditas } & \multicolumn{1}{c|}{ Profitabilitas } \\
\hline Kualitas Aset & & & 1.302 & 1.453 \\
\hline Kualitas Modal & & & $\mathbf{1 . 0 0 0}$ & $\mathbf{4 . 1 9 8}$ \\
\hline Likuiditas & & & & \\
\hline Profitabilitas & & & & \\
\hline
\end{tabular}

Sumber : olahan data 


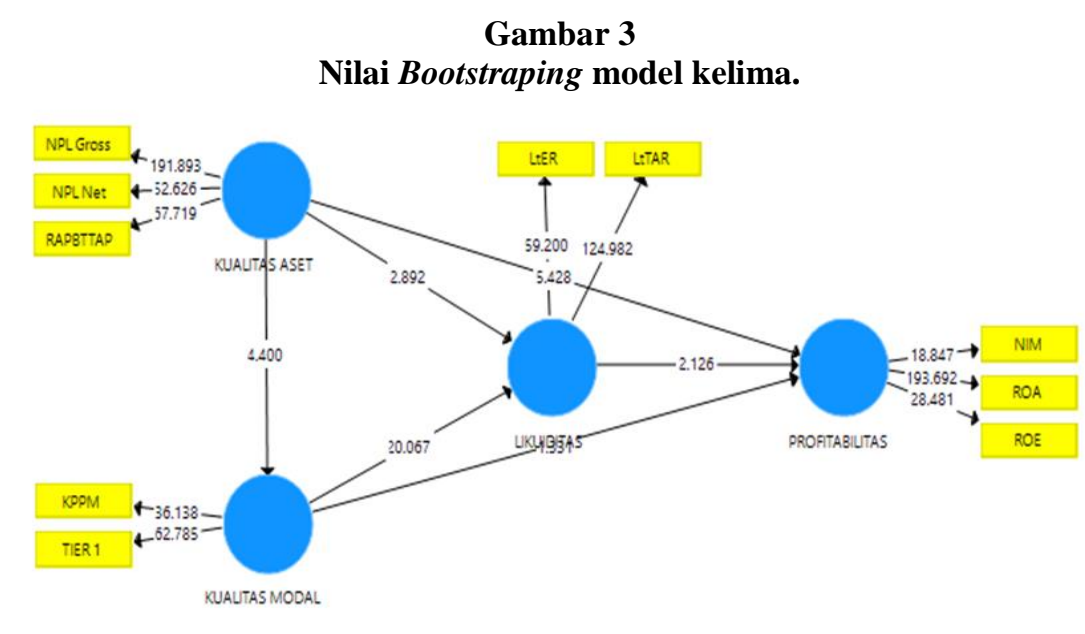

Hasil perhitungan (calculate) dengan melakukan Bootstraping pada Smart PLS 3.0, diperoleh nilai koeffisien jalur (path coefficients) yang terdiri dari original sample $(\mathrm{O})$, sample means $(\mathrm{M})$, standard deviation (STDEV), $\mathrm{T}$ statistics ([O/STDEV]) dan P values seperti pada tabel 4. Guna mengetahui besarnya pengaruh antar variabel dapat diketahui dari kolom original sample dan untuk melihat tingkat signifikasi dapat diketahui dari kolom $T$ statistics. Menurut Ghozali (2006), nilai $t$-stat yang berada diatas nilai 1,96 menunjukkan pengaruh yang signifikan dari masingmasing hipotesis. Selain itu untuk dapat mengetahui besarnya pengaruh antar variabel dapat diketahui juga dari besarnya $\mathrm{P}$ values, jika nilai $\mathrm{P}$ values lebih kecil (kurang) dari 0,05 atau sebesar 5\% maka hubungan antar variabel tersebut dikatakan berpengaruh, demikian juga jika nilai $\mathrm{P}$ values lebih besar (diatas) 0,05 maka hubungan antar variabel dikatakan tidak berpengaruh. Hasil perhitungan berdasarkan tabel 4. tersebut menunjukkan bahwa hanya variabel kualitas modal yang tidak berpengaruh terhadap profitabilitas.

Tabel 4

Nilai koeffisien jalur (path coefficients) hasil Bootstraping

\begin{tabular}{|c|c|c|c|c|c|}
\hline & Original Sample (O) & Sample Mean (M) & Standard Deviation (STDEV) & T Statistics ([O/STDEV]) & P Values \\
\hline Kualitas Aset -> Kualitas Modal & -0.481 & -0.481 & 0.109 & 4.400 & 0.000 \\
\hline Kualitas Aset -> Likuiditas & 0.180 & 0.169 & 0.062 & 2.892 & 0.004 \\
\hline Kualitas Aset -> Profitabilitas & -0.576 & -0.578 & 0.106 & 5.428 & 0.000 \\
\hline Kualitas Modal -> Likuiditas & -0.786 & -0.792 & 0.039 & 20.067 & 0.000 \\
\hline Kualitas Modal -> Profitabilitas & -0.278 & -0.302 & 0.209 & 1.331 & 0.184 \\
\hline Likuiditas -> Profitabilitas & -0.412 & -0.435 & 0.194 & 2.126 & 0.034 \\
\hline
\end{tabular}

Sumber : olahan data

Tabel 5

specific indirect effects hasil Bootstraping

\begin{tabular}{|c|c|c|c|c|c|}
\hline & Original Sample $(\mathrm{O})$ & Sample Mean (M) & Standard DeviatiOn (STDEV) & T Statistics ([O/STDEV]) & P Values \\
\hline Kualitas Aset -> Kualitas Modal -> Likuiditas & 0.378 & 0.380 & 0.084 & 4.525 & 0.000 \\
\hline Kualitas Aset -> Kualitas Modal -> Profitabilitas & 0.134 & 0.146 & 0.111 & 1.207 & 0.228 \\
\hline Kualitas Aset -> Likuiditas -> Profitabilitas & -0.074 & -0.073 & 0.043 & 1.712 & 0.087 \\
\hline Kualitas Modal -> Likuiditas -> Profitabilitas & 0.324 & 0.346 & 0.157 & 2.067 & 0.039 \\
\hline Kualitas Aset $->$ Kualitas Modal $->$ Likuiditas $->$ Profitabilitas & -0.156 & -0.165 & 0.084 & 1.847 & 0.065 \\
\hline
\end{tabular}

Sumber : olahan data

Hasil pengujian hipotesis dengan berdasarkan tabel 5 tersebut sabagai berikut:

1) Hipotesis pertama dalam penelitian ini adalah diduga kualitas aset berpengaruh signifikan terhadap likuiditas pada sub sektor perbankan di Bursa Efek Indonesia periode 2015 - 2019”. Pengujian hipotesis pertama variabel X1 yakni kualitas aset berpengaruh signifikan terhadap variabel $\mathrm{Y}$ yakni likuiditas, karena mempunyai nilai $\mathrm{P}$ values sebesar 0,004., dimana nilai $\mathrm{P}$ values tersebut lebih kecil dari 0.05 atau lebih kecil dari 5\% atau juga dapat dilihat pada nilai t statisik yakni sebesar 2,892 atau lebih besar dari 1,96. Hal ini menunjukkan terdapat cukup bukti empiris untuk menerima hipotesis pertama. Dengan demikian disimpulkan bahwa kualitas aset berpengaruh terhadap likuiditas.

2) Hipotesis kedua dalam penelitian ini adalah diduga kualitas modal berpengaruh signifikan terhadap likuiditas pada sub sektor perbankan di Bursa Efek Indonesia periode 2015 - 2019.” Pengujian hipotesis kedua variabel X2 yakni kualitas modal berpengaruh signifikan terhadap variabel $\mathrm{Y}$ yakni likuiditas, karena mempunyai nilai $\mathrm{P}$ values sebesar 0,000., dimana nilai $\mathrm{P}$ values tersebut lebih kecil dari 0.05 atau lebih kecil dari 5\% atau juga dapat dilihat 
pada nilai t statisik yakni sebesar 20,067 atau lebih besar dari 1,96. Hal ini menunjukkan terdapat cukup bukti empiris untuk menerima hipotesis kedua. Dengan demikian disimpulkan bahwa kualitas modal berpengaruh terhadap likuiditas.

3) Hipotesis ketiga dalam penelitian ini adalah diduga kualitas aset berpengaruh signifikan terhadap profitabilitas pada sub sektor perbankan di Bursa Efek Indonesia periode 2015 - 2019. Pengujian hipotesis kedua variabel X1 yakni kualitas aset berpengaruh signifikan terhadap variabel $\mathrm{Z}$ yakni profitabilitas, karena mempunyai nilai $\mathrm{P}$ values sebesar 0,000., dimana nilai $P$ values tersebut lebih keci dari 0.05 atau lebih kecil dari $5 \%$ atau juga dapat dilihat pada nilai t statisik yakni sebesar 5,248 atau lebih besar dari 1,96. Hal ini menunjukkan terdapat cukup bukti empiris untuk menerima hipotesis ketiga. Dengan demikian disimpulkan bahwa kualitas aset berpengaruh terhadap profitabilitas.

4) Hipotesis keempat dalam penelitian ini adalah diduga kualitas modal berpengaruh signifikan terhadap profitabilitas pada sub sektor perbankan di Bursa Efek Indonesia periode 2015 - 2019. Pengujian hipotesis kedua variabel X2 yakni kualitas modal berpengaruh signifikan terhadap variabel $\mathrm{Z}$ yakni profitabilitas, karena mempunyai nilai $\mathrm{P}$ values sebesar 0,184 atau sebesar $18,4 \%$, dimana nilai $\mathrm{P}$ values tersebut lebih besar dari 0.05 atau lebih besar dari $5 \%$ atau juga dapat dilihat pada nilai t statisik yakni sebesar 1,331 atau lebih kecil dari 1,96. Hal ini menunjukkan terdapat cukup bukti empiris untuk menolak hipotesis keempat. Dengan demikian disimpulkan bahwa kualitas modal tidak berpengaruh terhadap profitabilitas.

5) Hipotesis kelima dalam penelitian ini adalah diduga likuiditas berpengaruh terhadap profitabilitas pada sub sektor perbankan di Bursa Efek Indonesia periode 2015 - 2019. Pengujian hipotesis kelima, dimana variabel Y yakni likuiditas berpengaruh terhadap variabel $\mathrm{Z}$ yakni profitabilitas, karena mempunyai nilai $\mathrm{P}$ values sebesar 0,034 ., dimana nilai $\mathrm{P}$ values tersebut kurang dari 0,05 atau kurang dari $5 \%$ atau juga dapat dilihat pada nilai $\mathrm{t}$ statisik yakni sebesar 2,126 atau lebih besar dari 1,96. Hal ini menunjukkan terdapat cukup bukti empiris untuk menerima hipotesis kelima. Dengan demikian disimpulkan bahwa likuiditas berpengaruh terhadap profitabilitas.

6) Hipotesis keenam dalam penelitian ini adalah diduga kualitas aset dan kualitas modal berpengaruh signifikan terhadap profitabiltas dengan likuiditas sebagai variabel intervening pada sub sektor perbankan di Bursa Efek Indonesia periode 2015 - 2019. Pengujian hipotesis keenam, dimana variabel X1 yakni kualitas aset dan X2 yakni kualitas modal berpengaruh terhadap variabel $\mathrm{Z}$ yakni profitabilitas dengan variabel $\mathrm{Y}$ yakni likuiditas sebagai variabel intervening, karena mempunyai nilai $\mathrm{P}$ values sebesar 0,065 ., dimana nilai $\mathrm{P}$ values tersebut lebih dari 0,05 atau lebih dari 5\% atau juga dapat dilihat pada nilai t statisik yakni sebesar 1,847 atau lebih kecil dari 1,96. Hal ini menunjukkan tidak terdapat cukup bukti empiris untuk menerima hipotesis keenam. Dengan demikian disimpulkan bahwa kualitas aset dan kualitas modal tidak berpengaruh signifikan terhadap profitabiltas dengan likuiditas sebagai variabel intervening.

\section{Pengujian kelayakan model (goodness of fit)}

Pengujian terhadap nilai $R$-square sebagai hasil uji goodness of fit model dilihat dari besaran angka nilai $R$ square, yang dapat dilihat di dalam tabel $R$-square dari hasil running calculate model pada variabel endogen kualitas modal dan diperoleh angka sebesar 0,232 atau sebesar 23,2\%., pada variabel endogen likuiditas dan diperoleh angka sebesar 0,787 atau sebesar 78,7\%., sedangkan pada variabel endogen profitabilitas dan diperoleh angka sebesar 0,490 atau sebesar 49,0\%. Angka tersebut memperlihatkan bahwa besarnya pengaruh keragaman data yang dapat dijelaskan oleh model tersebut adalah sebesar 49,0\%., sisanya sebesar 51,0\% dijelaskan oleh variabel lain yang belum terkandung dalam model tersebut dan termasuk error. Hasil tersebut memberikan makna bahwa model penelitian ini merupakan model yang tergolong moderat, menurut Chin (1998) dalam Ghozali seperti pada kriteria penilian PLS, yang terlihat pada tabel 6 berikut:

Tabel 6

Nilai $\mathbf{R}^{2}$

\begin{tabular}{|l|r|r|}
\hline & R Square & Adjusted R Square \\
\hline Kualitas Modal & 0.232 & 0.217 \\
\hline Likuiditas & 0.787 & 0.778 \\
\hline Profitabilitas & 0.490 & 0.460 \\
\hline
\end{tabular}

Sumber : olahan data

Berdasarkan hasil penelitian di atas, maka dapat dijelaskan hasil penelitian ini berdasarkan uji hipotesis antaralain bahwa:

1) Pengaruh kualitas aset terhadap likuiditas pada sub sektor perbankan di Bursa Efek Indonesia periode 2015 2019. Kualitas asset berpengaruh signifikan terhadap likuiditas pada sub sector perbankan di Indonesia periode 2015-2019, dimana nilai t 2,892 > 1,96., nilai path coefficients pengaruh kualitas aset terhadap likuiditas sebesar 
0,180., yang bermakna jika terjadi kenaikan sebesar 1 satuan pada likuiditas maka akan terjadi kenaikan sebesar 0,180 satuan pada kualitas aset, yang mana terdapat pengaruh signifikan dengan nilai $\mathrm{P}$ values sebesar 0,004. Indikator kualitas aset dengan indikator NPL Gross mempunyai outer loading sebesar 0,990., indikator NPL Net mempunyai outer loading sebesar 0,958., indikator RAPBTTAP mempunyai outer loading sebesar 0,972., karena mempunyai outer loading diatas 0,7 yang berarti mampu mengkonstruk kualitas asset. Adapun indikator variabel likuiditas dengan indikator LtER memiliki nilai outer loading yakni sebesar 0,954., dan indikator LtTAR memiliki nilai outer loading yakni sebesar 0,963., yang berarti indikator tersebut mampu mengkonstruk likuiditas karena mempunyai outer loading diatas 0,7 ., sedangkan indikator LDR tidak mampu mengkonstruk variabel likuiditas karena dikeluarkan dari model. Penelitian ini berbeda dengan penelitian Hendra Fitrianto yang mana hasil penelitian menunjukkan bahwa NPL, NPA, ROE, dan BOPO tidak memliki pengaruh secara signifikan terhadap CAR (KPMM), serta penelitian ini menggunakan indikator yang lebih banyak.

2) Pengaruh kualitas modal terhadap likuiditas pada sub sektor perbankan di Bursa Efek Indonesia periode 2015 2019. Kualitas modal berpengaruh signifikan terhadap likuiditas pada sub sector perbankan di Indonesia periode 2015-2019, dimana nilai t statisik sebesar 20,067 > 1,96., nilai path coefficients sebesar sebesar -0,786., yang bermakna jika terjadi kenaikan sebesar 1 satuan pada kualitas modal maka akan terjadi penurunan sebesar 0,786 satuan pada likuiditas, yang mana terdapat pengaruh signifikan dengan nilai $\mathrm{P}$ values sebesar 0,004 . Indikator kualitas aset dengan indikator NPL Gross mempunyai outer loading sebesar 0,990., indikator NPL Net mempunyai outer loading sebesar 0,958., indikator RAPBTTAP mempunyai outer loading sebesar 0,972., karena mempunyai outer loading diatas 0,7 yang berarti mampu mengkonstruk kualitas asset. Adapun indikator variabel likuiditas dengan indikator LtER memiliki nilai outer loading yakni sebesar 0,955., dan indikator LtTAR memiliki nilai outer loading yakni sebesar 0,946., yang berarti indikator tersebut mampu mengkonstruk likuiditas karena mempunyai outer loading diatas 0,7., sedangkan indikator LDR tidak mampu mengkonstruk variabel likuiditas karena dikeluarkan dari model. Penelitian ini berbeda dengan penelitian Bukian yang mana hasil penelitian menunjukkan bahwa NPL dan LDR memiliki pengaruh positif dan signifikan terhadap CAR, ROA dan BOPO berpengaruh negatif dan signifikan terhadap CAR, serta penelitian ini menggunakan indikator yang lebih banyak.

3) Pengaruh kualitas aset terhadap profitabilitas pada sub sektor perbankan di Bursa Efek Indonesia periode 2015 2019. Kualitas aset berpengaruh signifikan terhadap variabel profitabilitas pada sub sector perbankan di Indonesia periode 2015-2019, dimana nilai t sebesar 5,428 > 1,96., nilai path coefficients sebesar sebesar -0,576., yang bermakna jika terjadi kenaikan sebesar 1 satuan pada kualitas aset maka akan terjadi penurunan sebesar 0,576 satuan pada profitabilitas, yang mana terdapat pengaruh signifikan dengan nilai $\mathrm{P}$ values sebesar 0,000 . Indikator kualitas aset dengan indikator NPL Gross mempunyai outer loading sebesar 0,990., indikator NPL Net mempunyai outer loading sebesar 0,958., indikator RAPBTTAP mempunyai outer loading sebesar 0,972., karena mempunyai outer loading diatas 0,7 yang berarti mampu mengkonstruk kualitas asset. Adapun indikator variabel profitabilitas dengan indikator NIM memiliki nilai outer loading yakni sebesar 0,816., indikator ROA memiliki nilai outer loading yakni sebesar 0,976., dan indikator ROE memiliki nilai outer loading yakni sebesar 0,873., yang berarti indikator tersebut mampu mengkonstruk profitabilitas karena mempunyai outer loading diatas 0,7 ., sedangkan indikator BOPO tidak mampu mengkonstruk variabel profitabilitas karena dikeluarkan dari model. Penelitian ini berbeda dengan penelitian Budiwati yang mana hasil penelitian menunjukkan bahwa non performing assets mempunyai pengaruh yang signifikan terhadap net interest margin, loan to deposits ratio mempunyai pengaruh yang signifikan terhadap net interest margin dan rata-rata net interest margin pada sampel penelitian adalah 6,49., serta penelitian ini menggunakan indikator yang lebih banyak.

4) Pengaruh kualitas modal terhadap profitabilitas pada sub sektor perbankan di Bursa Efek Indonesia periode 2015 - 2019. Kualitas modal tidak berpengaruh signifikan terhadap variabel profitabilitas pada sub sektor perbankan di Indonesia periode 2015-2019, dimana nilai t sebesar 1,331 < 1,96., nilai path coefficients sebesar sebesar -0,278., yang bermakna jika terjadi kenaikan sebesar 1 satuan pada kualitas modal maka akan terjadi penurunan sebesar 0,278 satuan pada profitabilitas, yang mana tidak terdapat pengaruh signifikan dengan nilai $\mathrm{P}$ values sebesar 0,184. Indikator kualitas modal dengan indikator KPMM mempunyai outer loading sebesar 0,936., dan indikator TIER 1 mempunyai outer loading sebesar 0,949., karena mempunyai outer loading diatas 0,7 yang berarti mampu mengkonstruk kualitas modal. Adapun indikator variabel profitabilitas dengan indikator NIM memiliki nilai outer loading yakni sebesar 0,816., indikator ROA memiliki nilai outer loading yakni sebesar 0,976., dan indikator ROE memiliki nilai outer loading yakni sebesar 0,873., yang berarti indikator tersebut mampu mengkonstruk profitabilitas karena mempunyai outer loading diatas 0,7., sedangkan indikator BOPO tidak mampu mengkonstruk variabel profitabilitas karena dikeluarkan dari model. Penelitian ini berbeda dengan penelitian Hermina yang mana hasil penelitian menunjukkan bahwa aspek permodalan berpengaruh positif dan signifikan terhadap kinerja keuangan, kualitas aset berpengaruh positif dan signifikan terhadap kinerja keuangan, 
aspek manajemen berpengaruh positif dan signifikan terhadap kinerja keuangan, efisiensi berpengaruh positif dan tidak signifikan terhadap kinerja keuangan, likuiditas berpengaruh negatif dan signifikan terhadap kinerja keuangan dan sensitivitas atas risiko berpengaruh negatif dan signifikan terhadap kinerja keuangan, serta penelitian ini menggunakan indikator yang lebih banyak.

5) Pengaruh likuiditas terhadap profitabilitas pada sub sektor perbankan di Bursa Efek Indonesia periode 2015 2019. Likuiditas berpengaruh signifikan terhadap variabel profitabilitas pada sub sektor perbankan di Indonesia periode 2015-2019, dimana nilai t sebesar 2,126 > 1,96., nilai path coefficients sebesar sebesar -0,412., yang bermakna jika terjadi kenaikan sebesar 1 satuan pada profitabilitas maka akan terjadi penurunan sebesar 0,412 satuan pada likuiditas, yang mana terdapat pengaruh signifikan dengan nilai $\mathrm{P}$ values sebesar 0,034 . Indikator likuiditas dengan indikator LtER mempunyai outer loading sebesar 0,953., dan indikator LtTAR mempunyai outer loading sebesar 0,963 ., karena mempunyai outer loading diatas 0,7 yang berarti mampu mengkonstruk likuiditas sedangkan indikator LDR tidak mampu mengkonstruk variabel likuiditas karena dikeluarkan dari model. Adapun indikator variabel profitabilitas dengan indikator NIM memiliki nilai outer loading yakni sebesar 0,816., indikator ROA memiliki nilai outer loading yakni sebesar 0,976., dan indikator ROE memiliki nilai outer loading yakni sebesar 0,873., yang berarti indikator tersebut mampu mengkonstruk profitabilitas karena mempunyai outer loading diatas 0,7., sedangkan indikator BOPO tidak mampu mengkonstruk variabel profitabilitas karena dikeluarkan dari model. Penelitian ini berbeda dengan penelitian Budiwati yang menunjukkan bahwa non performing assets mempunyai pengaruh yang signifikan terhadap net interest margin, loan to deposits ratio mempunyai pengaruh yang signifikan terhadap net interest margin dan rata-rata net interest margin pada sampel penelitian sebesar 6,49., serta penelitian ini menggunakan indikator yang lebih banyak.

6) Pengaruh kualitas aset dan kualitas modal terhadap profitabiltas dengan likuiditas sebagai variabel intervening pada sub sektor perbankan di Bursa Efek Indonesia periode 2015 - 2019. Kualitas aset dan kualitas modal berpengaruh terhadap variabel profitabilitas dengan variabel likuiditas sebagai variabel intervening pada sub sektor perbankan di Indonesia periode 2015-2019, dimana nilai t statisik yakni sebesar 1,847 atau lebih kecil dari 1,96., nilai path coefficients sebesar sebesar -0,156., yang bermakna jika terjadi kenaikan sebesar 1 satuan pada profitabilitas maka akan terjadi penurunan sebesar 0,156 satuan pada kualitas aset dan kualitas modal, yang mana tidak terdapat pengaruh signifikan dengan nilai $P$ values sebesar 0,065 .

Indikator kualitas aset dengan indikator NPL Gross mempunyai outer loading sebesar 0,990., indikator NPL Net mempunyai outer loading sebesar 0,958., indikator RAPBTTAP mempunyai outer loading sebesar 0,972., karena mempunyai outer loading diatas 0,7 yang berarti mampu mengkonstruk kualitas asset. Indikator kualitas modal dengan indikator KPMM mempunyai outer loading sebesar 0,936., dan indikator TIER 1 mempunyai outer loading sebesar 0,949., karena mempunyai outer loading diatas 0,7 yang berarti mampu mengkonstruk kualitas modal. Indikator likuiditas dengan indikator LtER mempunyai outer loading sebesar 0,953., dan indikator LtTAR mempunyai outer loading sebesar 0,963., karena mempunyai outer loading diatas 0,7 yang berarti mampu mengkonstruk likuiditas sedangkan indikator LDR tidak mampu mengkonstruk variabel likuiditas karena dikeluarkan dari model. Adapun indikator variabel profitabilitas dengan indikator NIM memiliki nilai outer loading yakni sebesar 0,816., indikator ROA memiliki nilai outer loading yakni sebesar 0,976., dan indikator ROE memiliki nilai outer loading yakni sebesar 0,873., yang berarti indikator tersebut mampu mengkonstruk profitabilitas karena mempunyai outer loading diatas 0,7., sedangkan indikator BOPO tidak mampu mengkonstruk variabel profitabilitas karena dikeluarkan dari model. Penelitian ini berbeda dengan penelitian yang ada sebelumnya pada penelitian terdahulu karena menggunakan variabel intervening likuiditas, serta penelitian ini menggunakan indikator yang lebih banyak.

\section{Simpulan}

Penelitian ini diperoleh berdasarkan analisis terhadap hasil penelitian telah dijelaskan pada bab sebelumnya, maka dapat ditarik kesimpulan yaitu:

1. Kualitas modal berpengaruh signifikan terhadap likuiditas pada sub sektor dengan nilai koeefisien jalur sebesar 0,180 perbankan di Bursa Efek Indonesia periode 2015 - 2019.

2. Kualitas modal berpengaruh signifikan terhadap likuiditas dengan nilai koeefisien jalur sebesar $-0,786$ pada sub sektor perbankan di Bursa Efek Indonesia periode 2015 - 2019.

3. Kualitas aset berpengaruh signifikan terhadap profitabilitas dengan nilai koeefisien jalur sebesar $-0,576$ pada sub sektor perbankan di Bursa Efek Indonesia periode 2015 - 2019.

4. Kualitas modal tidak berpengaruh signifikan terhadap profitabilitas pada sub sektor perbankan di Bursa Efek Indonesia periode 2015 - 2019.

5. Likuiditas berpengaruh signifikan terhadap profitabilitas dengan nilai koeefisien jalur sebesar $-0,412$ pada sub sektor perbankan di Bursa Efek Indonesia periode 2015 - 2019. 
Pantun Bukit dan Rika Syahrianti, Pengaruh Kualitas Aset dan Kualitas Modal Terhadap Profitabilitas dengan Likuiditas Sebagai Variabel Intervening Pada Sub Sektor Perbankan di Bursa Efek Indonesia Periode 2015 - 2019

6. Kualitas aset dan kualitas modal tidak berpengaruh signifikan terhadap profitabilitas dengan likuiditas sebagai variabel intervening pada sub sektor perbankan di Bursa Efek Indonesia periode 2015 - 2019.

\section{Daftar Pustaka}

Baridwan, Zaki. (2008). Sistem Akuntansi Penyusunan Prosedur dan Metode. Edisi Kelima. Yogyakarta: BPPE.

Brigham E, Houston J, (2001), Manajemen Keuangan, Buku 1, Edisi Kedelapan, Penerbit Airlangga, Jakarta.

Brigham, F Eugene dan Joul F Houston. (2006), Dasar-Dasar Manajemen Keuangan, Edisi Kesepuluh, Salemba Empat, Jakarta.

Budiwati, Hesti \& Ainun Jariah, (2012), Analisis Non Performing Assets Dan Loan To Deposits Ratio Serta Pengaruhnya Terhadap Net Interest Margin Sebagai Indikator Spread Based Pada Bank Umum Swasta Nasional Di Indonesia Periode 2004 - 2007., Jurnal Wiga Vol.2, No.2, pp.90-102.

Bukian, Ni Made Winda Parascintya \& Gede Merta Sudhiartha, (2015), Pengaruh Kualitas Aset, Likuiditas, Rentabilitas Dan Efisiensi Operasional Terhadap Rasio Kecukupan Modal. E-Jurnal Unud, Vol. 4, No. 4.

Dendawijaya, Lukman. (2009). Manajemen Perbankan. Jakarta: Ghalia Indonesia

Fabbozi, Frank J, (1999), Manajemen investasi, Salemba Empat, Jakarta.

Fahmi, Irham. (2012).Analisis Kinerja Keuangan, Bandung: Alfabeta.

Fahmi, Irham. (2012), Manajemen Investasi, Jakarta: Salemba Empat

Fahmi, Irham. (2014). Pengantar Manajemen Keuangan, Bandung: Alfabeta.

Ferdinand, Augusty (2006). Metode Penelitian Manajemen: Pedoman Penelitian untuk skripsi, Tesis dan Disertai Ilmu Manajemen. Semarang: Universitas Diponegoro.

Fitrianto, Hendra \& Wisnu Mawardi, (2006)., Analisis Pengaruh Kualitas Aset, Likuiditas, Rentabilitas, Dan Efisiensi Terhadap Rasio Kecukupan Modal Perbankan Yang Terdaftar Di Bursa Efek Jakarta., Jurnal Studi Manajemen \& Organisasi, Vol.3, No.1, pp.1-11.

Ghozali, Imam. (2001). Pokok-pokok Analisis Laporan Keuangan. Yogyakarta: BPFE.

Ghozali Imam. (2009). Aplikasi Analisis Multivariate dengan Program SPSS. Penerbit: Universitas Dipenogoro. Semarang,

Ghozali, Imam. (2013). Aplikasi Analisis Multivariate dengan Program IBM SPSS 21 Update PLS Regresi. Semarang: Badan Penerbit Universitas Diponegoro.

Harahap, Sofyan Syafri, (2010), Analisis Kritis Atas Laporan Keuangan, Jakarta: PT. Raja Grafindo Persada,

Hartono, Agus. 2010. Manajemen Keuangan. Edisi keempat. Yogyakarta : BPFE.

Hanafi, Mahduh dan Abdul Halim, (2012), Analisis Laporan Keuangan. Yogyakarta: (UPP) STIM YKPN.

Hasan, Iqbal, (2009), Analisis Data Penelitian Dengan Statistik, Bumi Aksara, Jakata.

Hermina, Tinneke \& Wufron., (2017), Aspek Permodalan, Kualitas Aset, Manajemen, Efisiensi, Likuiditas Dan Sensitivitas Risiko Pasar Dalam Menentukan Kinerja Keuangan Sektor Perbankan Di Bursa Efek Indonesia. Jurnal Wacana Ekonomi, Vol.17, No.01, pp. 1-12.

Husnan, Suad, (1998), Manajemen Keuangan : Teori dan Penerapan : Edisi Ke enam, BPFE, Yogyakarta. Husnan, Suad, (2003), Dasar-Dasar Teori Portofolio dan Analisis Sekuritas, UPP AMP YKPN, Yogyakarta Husnan, Suad. 2011, Dasar-Dasar Manajemen Keuangan, unit Penerbit dan Pencetakan (UPP)-AMP ,YKPN, Yogyakarta.

Jogiyanto, (2010), Analisis Investasi dan Teori Portofolio, Gajah Mada Press, Yogyakarta.

Jumingan, (2009), Analisis Laporan Keungan, Bumi Aksara, Jakarta.

Kamaludin, dan Rini Indriani. (2012). Manajemen keuangan. Edisi Revisi. CV. Bandar Maju. Bandung.

Kasmir, (2009). Pengantar Manajemen Keuangan Edisi Kedua, Jakarta : Kencana Prenada Media Group.

Kasmir, Jakfar. (2008), Analisis Laporan Keuangan, PT RAJAGRAFINDO PERSADA, Jakarta.

Kasmir, (2014), Analisis Laporan Keuangan, Edisi Satu. Cetakan ketujuh. Jakarta: PT Raja Grafindo Perkasa.

Kodifikasi Peraturan Bank Indonesia, (2012). LIabilitas Dan Modal, Pusat Riset dan Edukasi Bank Sentral Bank Indonesia.

Kodifikasi Peraturan Bank Indonesia, (2012). Aset, Pusat Riset dan Edukasi Bank Sentral Bank Indonesia.

Latumerisa, Julius R, (1999), Mengenal Aspek-aspek Operasional Bank Umum, Bumi Aksara, Jakarta.

Manullang, (2008), Dasar-Dasar Manajemen, Yogyakarta: Ghalia Indonesia.

Martono dan Harjito (2008)., Manajemen Keuangan, Yogyakarta, Ekonisia.

Munawir. S, (2007), Analisa Laporan Keuangan, Yogyakarta: Liberty.

Peraturan Bank Indonesia Nomor: 6/10/PBI/2004, Tentang Sistem Penilaian Tingkat Kesehatan Bank Umum

POJK No 11/POJK.03/2016, Tentang Kewajiban Penyediaan Modal Minimum (KPMM)

POJK No 40/POJK.03/2019, Tentang Penilaian Kualitas Asset Bank Umum.

Prihadi, Toto. (2011). Analisis Laporan Keuangan Teori dan Aplikasi Jakarta: PPM 
Pantun Bukit dan Rika Syahrianti, Pengaruh Kualitas Aset dan Kualitas Modal Terhadap Profitabilitas dengan Likuiditas Sebagai Variabel Intervening Pada Sub Sektor Perbankan di Bursa Efek Indonesia Periode 2015 - 2019

Riyanto, Bambang. (2001). Dasar-dasar Pembelajaran Perusahaan. BPFE. Yogyakarta

Riyanto, Bambang. (2010). Dasar-dasar Pembelajaran Perusahaan. BPFE. Yogyakarta.

Ryan dan Miyosi (2013), Membuat Laporan Keuangan Gampang, Penerbit Dunia Cerdas, Jakarta.

Sartono, R Agus, (2001), Manajemen Keuangan: Teori dan Aplikasi, Edisi 4 BPFE, Jogjakarta.

Samsul, Mohammad, (2006), Pasar Modal Dan Manajemen Portofolio, Erlangga, Jakarta.

Siagian, (2013), Manajemen Sumber daya Manusia, Bumi aksara, jakarta.

Siamat, Dahlan, (1993), Manajemen Bank Umum, Intermedia, Jakarta.

Sudana, I Made. (2011). Manajemen Keuangan Perusahaan Teori dan Praktik, ERLANGGA, Surabaya.

Sugiyono. (2010). Metode Penelitian Kuantitatif, Kualitatif dan R\&D. Penerbit Alfabeta, Bandung.

Sugiyono, (2013). Metode Penelitian Manajemen. Penerbit: Afabeta, Bandung.

Tandelilin, Eduardus, (2001), Analisis Investasi dan Manajemen Portofolio, BPFE, Yogyakarta.

Tandelilin, Eduardus, (2010), Analisis Investasi dan Manajemen Portofolio, BPFE, Yogyakarta.

Taswan. (2010). Manajemen Perbankan Konsep, Teknik, dan Aplikasi, edisi 2, Yogyakarta. UPP STIM YKPN.

Undang-undang nomor 10 Tahun 1998 tentang Perbankan.

Van Horne James C dan John M. (2009). Prinsip-prinsip Manajemen Keuangan. Jakarta : Salemba Empat

Zubir, Zalmi. (2011), Manajemen Portofolio: Penerapannya dalam Investasi Saham. Salemba Empat: Jakarta.. 